\title{
有病者の口腔外科的処置に関する調査
}

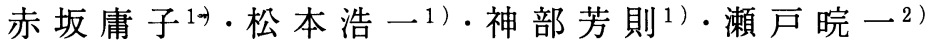 \\ 山本美 朗 ${ }^{3)}$. 白川正順 ${ }^{4}$ ) - 吉澤 信 夫 $^{5}$ ) - 埜口五十雄 ${ }^{6)}$ \\ 寶田 博 ${ }^{7)}$. 山田祐敬 ${ }^{8)}$. 坂下英明 ${ }^{9)}$. 小野富昭 ${ }^{10)}$
}

\section{Study of the oral surgical treatment of medically compromised patients}

\author{
Yoko Akasaka 1$) \cdot$ Koichi Matsumoto $\left.{ }^{1}\right) \cdot$ Yoshinori Jinbu 1$) \cdot$ Kan-ichi Seto $^{2}$ ) \\ Yoshiro Yamamoto $\left.{ }^{3}\right) \cdot$ Masayori Shirakawa 4$) \cdot$ Nobuo Yoshizawa $\left.^{5}\right) \cdot$ Isoo Noguchi $^{6}$ ) \\ Hiroshi Takarada $\left.{ }^{7}\right) \cdot$ Yutaka Yamada $\left.{ }^{8}\right) \cdot$ Hideaki SaKashita 9$) \cdot$ Tomiaki Ono10)
}

\begin{abstract}
The dental and oral surgical treatment of medically compromised patients has been avoided or contraindicated because such patients are at high medical risk. However, the oral surgery of these patients is important for the relief of oral discomfort and may have a good influence on the course and outcome of their systemic disease.

We analyzed the treatment items and times before, during, and after oral surgery in high risk patients, as compared with normal patients. The subjects comprised 96 patients (male, 58; female, 38) treated at 10 hospitals. Their systemic diseases were restricted to 6 kinds: cardiovascular disease, diabetes mellitus, hematologic disease, hemodialysis, infectious
\end{abstract}

1 ) 自治医科大学歯科口腔外科学講座 (主任 : 赤坂庸子教授)

2 ) 鶴見大学歯学部第 1 口腔外科学講座 (主任 : 瀬戸晥一教授)

3 ) 明海大学歯学部口腔外科学第 1 講座 (主任 : 山本美朗教授)

4) 日本歯科大学歯学部口腔外科学教室第 1 講座 (主任 : 白川正順教授)

5 ) 山形大学医学部歯科口腔外科学講座 （主任 : 吉澤信夫教授）

6 ) 防衛医科大学校歯科口腔外科 (主任 : 埜口五十雄教授)

7 ) 三井記念病院歯科口腔外科 （主任：寶田 博部長）

8 ) 市立岡崎病院歯科口腔外科 （主任：山田祐敬部長）

9 ) 石川県立中央病院歯科口腔外科 (主任 : 坂下英明医長)

10）国立国際医療センター歯科口腔外科 （主任：小野富昭医長）

1 ) Dept. of Dentistry and Oral Surgery, Jichi Medical School (Chief: Prof. Yoko Akasaka)

2 ) First Dept. of Oral and Maxillofacial Surgery, School of Dental Medicine Tsurumi University (Chief: Prof. Kan-ichi Seto)
3 ) First Dept. of Oral and Maxillofacial Surgery, Meikai University School of Dentistry (Chief: Prof. Yoshiro Yamamoto)

4 ) Dept. of Oral and Maxillofacial Surgery I, The Nippon Dental University, School of Dentistry at Tokyo (Chief: Prof. Masayori Shirakawa)

5 ) Dept. of Dentistry and Oral Surgery, School of Medicine, Yamagata University (Chief: Prof. Nobuo Yoshizawa)

6 ) Dept. of Oral and Maxillofacial Surgery, National Defense Medical College (Chief: Prof. Isoo Noguchi)

7 ) Dept. of Oral and Maxillofacial Surgery, Mitsui Memorial Hospital (Chief: Hiroshi Takarada)

8 ) Dept. of Oral and Maxillofacial Surgery, Okazaki Municibal Hospital (Chief: Yutaka Yamada)

9 ) Dept. of Dentistry and Oral Surgery, Ishikawa Prefectural Central Hospital (Chief: Hideaki Sakashita)

10) Dept. of Dentistry and Oral Surgery, International Medical Center of Japan (Chief: Tomiaki Ono)

受付日 : 平成 9 年 12 月 2 日 
disease (viral hepatitis, HIV infection), and patients receiving steroids, anticoagulants, and antitumor drugs.

The average number of treatment items before, during, and after oral surgery was 13 , and 360.2 min were required for treatment per patient. Furthermore, for tooth extraction, the treatment items of the patients who were treated on an inpatient basis were 2 -fold that of the patients treated on an outpatient basis, and the treatment items of medically compromised patients were 3 -fold that of normal patients.

Key words: medically compromised patients (有病者), oral surgical treatment (口腔外科的処置)

緒 言

近年わが国における高齢化や社会生活の複雑化に伴 い, 有病者が増加し ${ }^{1)}$ 歯科口腔外科治療を行ううえで, 困難をきたす症例も少なくない2). 従来, 全身疾患を 有するために, 口腔外科的処置は困難との理由で, 治 療を回避されてきたような症例においても，患者側に 立って考えるならば, 適切な医療を受けることができ るか否かは患者の日常生活のクオリティに大きくかか わる問題である.したがって, そのような患者に対す る医療を広げる努力はわれわれに課せられた任務とも 言えよう。

しかし，一方に扔いて，有病者に対して抜歯などの 観血的処置を行うには，患者においても，またわれわ れ医療を担当する側においてもそれ相当のリスクを負 わなければならない. それらの患者に対して, 危険を 未然に防ぎより安全に口腔外科的処置を進めるために は高度の医療知識と技術が要求されることは改めてい うまでもないことである.

今回われわれは, かなりのリスクを伴う患者に対し て腔外科的処置を進めるうえで, 術前, 術中, 術後 にいかなる検査および処置が必要とされるか，また， そのために要する時間はどのくらいかなどを具体的に 把握する目的で調査を行った。

\section{対象疾患および調查方法}

1. 対象疾患は主要な全身疾患に限定し, さらにお のおのの疾患においても, 口腔外科的処置に際してき わめてリスクの高い患者に絞った，すなわち，口腔外 科的処置とくに観血的処置を行う場合に健常者と同じ には取り扱えない, 何らかの対策が必要な全身的疾患 として心疾患, 糖尿病, 血液疾患, 透析患者, 感染症 （ウィルス肝炎, HIV）および特殊な薬物療法患者の 5 種類の疾患を選択した. またおのおのの疾患において も重症度の高いものに限定して調查を行うこととし， 特定の条件を個々の症例を選択する際の基準とした （表 1 ). 対象疾患とその選択の基準は表 1 のとおりで
ある。

2. 調査の方法は, 術前, 術中, 術後において必要と 考えられる検查および処置の項目を設定し，調査票を 作成し（表 2 ），各症例毎に実際に行った検查および処 置をチェックした，それらを集計，分析して，どのよ うな検查および処置が全身疾患の管理として行われた のか, その数, 内容を明らかにするとともに要した時 間についても検討した。ささらに同様の調査を全身疾患 のない抜歯症例についても行い, 有病者群の抜歯との 比較も行った。

\section{結果}

\section{1. 対象症例}

対象症例は調査を行った114例のうち, 記載に不備 のあったものを除き, 男性58例，女性38例の計96例で ある (表 3 ). 年齢は 9 歳から 82 歳までにわたり, 平均 年齢は 55.8 歳であった。年代別の分布をみると, 50 歳 台と60歳台で54例と全症例の半数を超えていた（表 4 ）. このことは歯科医療機関に受診する有病者がこの年代 層に最も多いことを示すものといえる。

\section{2 . 基礎疾患別症例数}

対象の96例を基礎疾患別にみると, 特定の疾患を単 一にもっているものは96例中87例で, その疾患別の内 訳は心疾患が33例と最も多く, 次いで感染症, 糖尿病 が各13例，血液疾患と透析患者が各10例であった。 な お, 口腔外科的処置を行ううえで特に問題となる抗凝 血薬, ステロイド剤, 抗癌剂を投与中の症例が21例あつ たが, そのうち13例は心疾患，2例は脳梗塞，またステ ロイド療法が 5 例, 抗癌剂は 1 例であった（表 5 )。

複数の基礎疾患を有していたものは 9 例で, 疾患数 はいずれも 2 疾患であり，9例中 7 例は感染症を合併 しており，そのうち HCV 抗体陽性者が 3 例, HIV 抗 体陽性者が 3 例であった（表 6 ）。

\section{3 . 口腔外科的処置および症例数}

対象96例に対して行った口腔外科的処置は普通抜歯 が圧倒的に多く68例, その他は埋伏歯抜歯, 腫瘍切除, 歯肉切除などである（表 7 ）. 30例は入院下に治療を行っ たものである. 
表 1 対象疾患と症例の選択基準

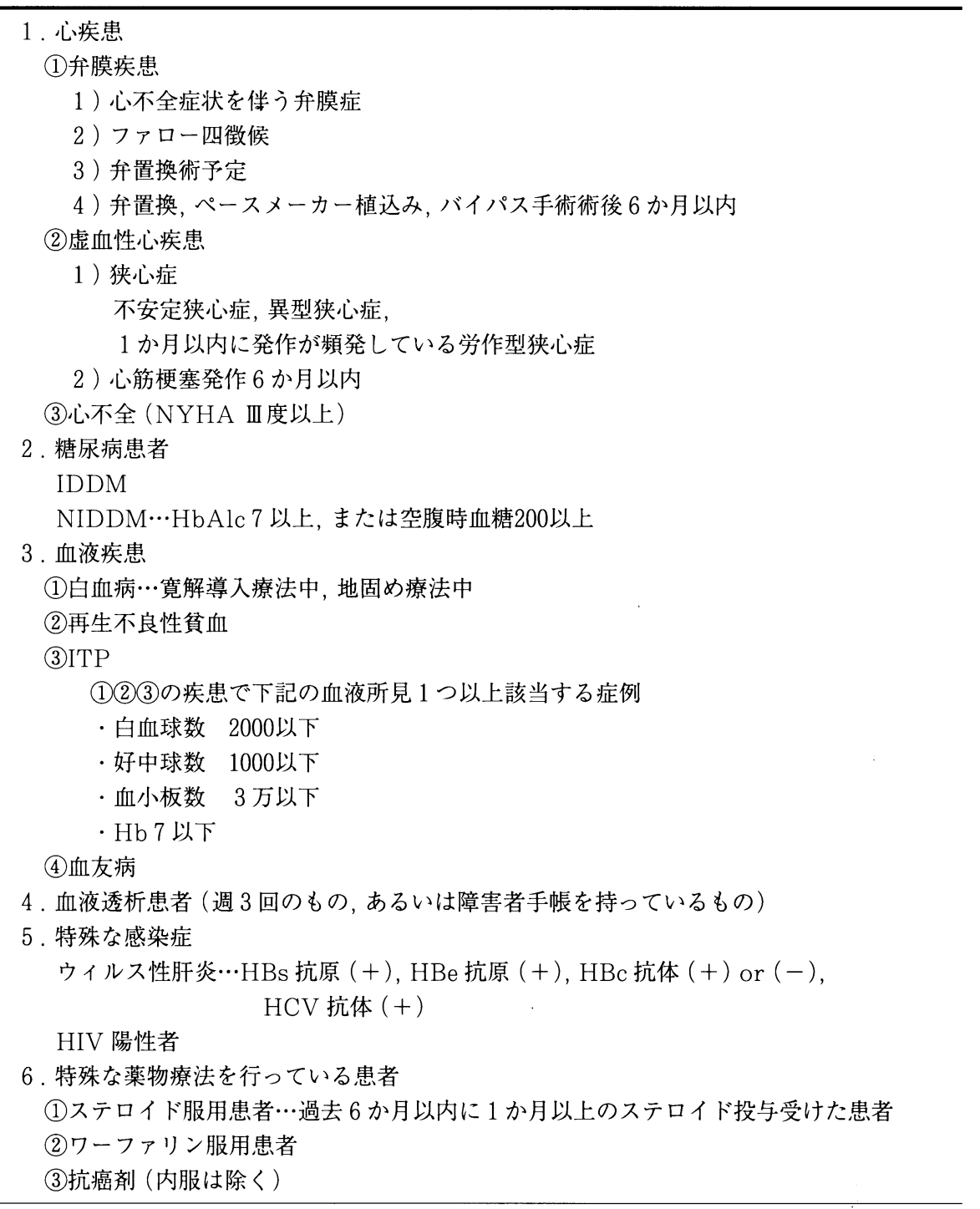

\section{4. 術前, 術中, 術後の検査および処置数について}

1) 平均検查および処置数

有病者に対して口腔外科的処置を行う際に術前, 術 中, 術後にそれぞれどのくらいの検査および処置が必 要であるかを検討した（表 8 ).

外来で口腔外科的処置を行った症例と, 入院症例で は, 術前, 術中, 術後のいずれにおいても入院症例の 方が約 2 倍と多かった. 外来, 入院を合わせると術前 の検查および処置は13項目中 4.9 項目, 術中4.1項目, 術 後は4.0項目で, 合計すると 1 例当たり 1 回の口腔外科
的処置で平均13.0項目の術前, 術中, 術後の処置を行つ たことになる。

2 ) 口腔外科的処置別にみた検査および処置数 外来で歯科口腔外科処置を行った70例についてみる と, 最も多かったのは囊胞摘出症例と腫瘍切除症例で, どちらも16項目の検查および処置を必要としていた． 次が抜歯で, 埋伏歯が11.0項目, 普通抜歯が10.2項目で, この両者にはあまり差がなかった，その他は歯石除去， 歯肉切除, インプラント植立などの順であった（表 9 ). 入院して口腔外科的処置を行った症例は 30 例, 全体 
表 2 特殊疾患の口腔外科処置に関する調査票

調查票番号*

*記入しないで下さい

各施設のカルテ番号 ，施設名

担当医

患者名:

手術日 199 年

月 $\quad$ 日

口腔領域钐断名および処圈

拔齿（部位：，普通抜画，難抜齿，埋伏）

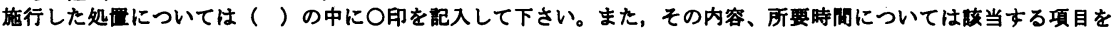

○で囲むか（）の中に記入して下さい。

術前に行った処相

1 （）他科へのコンサルテーション

2（）バイタルチェック（体沮, 眼拍, 呼吸, その他 :

3（）血圧测定（回：初診時, 術直前, その他）

4（）心值图测定

5（） その他特殊梌查（

6（）血㳸㭘查（血液一般，生化，その他：

7 ( ) スプリント作製

8（）会血蔀供処辰

9（）術前投薬（感染予防，その他 :

10 （）術前薬物コントロール（娍至，增量，中止，その他）

11 （）入院手綿き、オリエンテーション

12 ( ) 栄落管理、指主

13（）その他の術前処嘈（

)

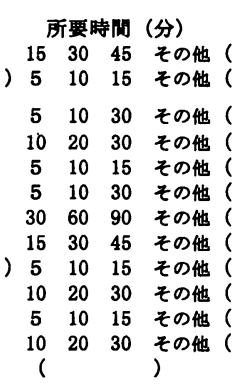

術中に行った処置

1 （）麻䡃法（局麻 : エピ入り，エピ無し） (全麻 :

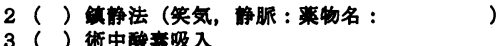

4（）バイタルチェック（体沮, 脈拍, 呼吸, その他 :

5 （）血圧测定（回）

6（）心蛙図モニタリング

7 ( ) その他のモヒダ- (

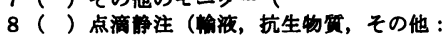

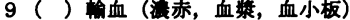

10 （）術中萝物内服（薬物名

11 （）局所止血法（戦合，その他:

12（）スプリント使用（址血用，創部保讙用）

13 （）他科へのコンサルテーション

14（）その他の術中処囯（

$5 \quad 10 \quad 15$ その他（ 全麻碎時阙

306090 その他

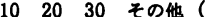

) 51015 その他 (

153060 その他 (

\begin{tabular}{llll}
15 & 30 & 60 & その他 \\
\hline
\end{tabular}

) $1530 \quad 60$ その他

) $1530 \quad 60$ その他

$\begin{array}{llll}30 & 60 & 90 & \text { その他 }\end{array}$

$510 \quad 15$ その他

$1530 \quad 45$ その他

\begin{tabular}{llll}
15 & 30 & 45 & その他 \\
\hline
\end{tabular}

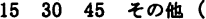

術後に行った処度

1 （）バイタルチェック（体沮, 眼拍, 呼吸, その他 :

2（）血圧测定（回）

3 （）心视図测定、モニタリング

4（）血液㭘查(血液一般, 生化, その他：），

6（）スプリント部整あるいは除去

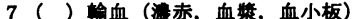

8（）点滴軤注（喻液, 抗生物窗, その他 :

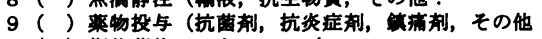

$10 （ ）$ 術後薬物コントロール（

11 （）他科へのコンサルテーション

12 () 㤎染器具類の処理・消童

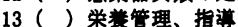

14（）特別な口腔湾骦指道

15 （）その他の術後処置（後出血処贯，その他 :

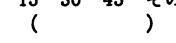

\begin{tabular}{|c|c|c|c|}
\hline ) 10 & 20 & 30 & その他（ \\
\hline 5 & 10 & 15 & その他（ \\
\hline 10 & 20 & 30 & その他（ \\
\hline 5 & 10 & 30 & その他（ \\
\hline 5 & 10 & 15 & その他（ \\
\hline 15 & 30 & 45 & その他 ( \\
\hline 30 & 60 & 90 & その他（ \\
\hline ) 15 & 30 & 60 & その他（ \\
\hline 5 & 10 & 15 & その他（ \\
\hline ) 10 & 20 & 30 & その他（ \\
\hline 15 & 30 & 45 & その他（ \\
\hline 10 & 20 & 30 & その他 \\
\hline 10 & 20 & 30 & その他（ \\
\hline 10 & 20 & 30 & その他（ \\
\hline
\end{tabular}

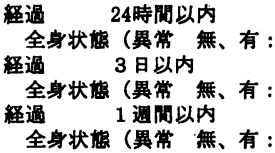

）局所（異常 無、有
） 局所（異常 無、有
） 局所（異常 無、有


表 3-1 症例一覧

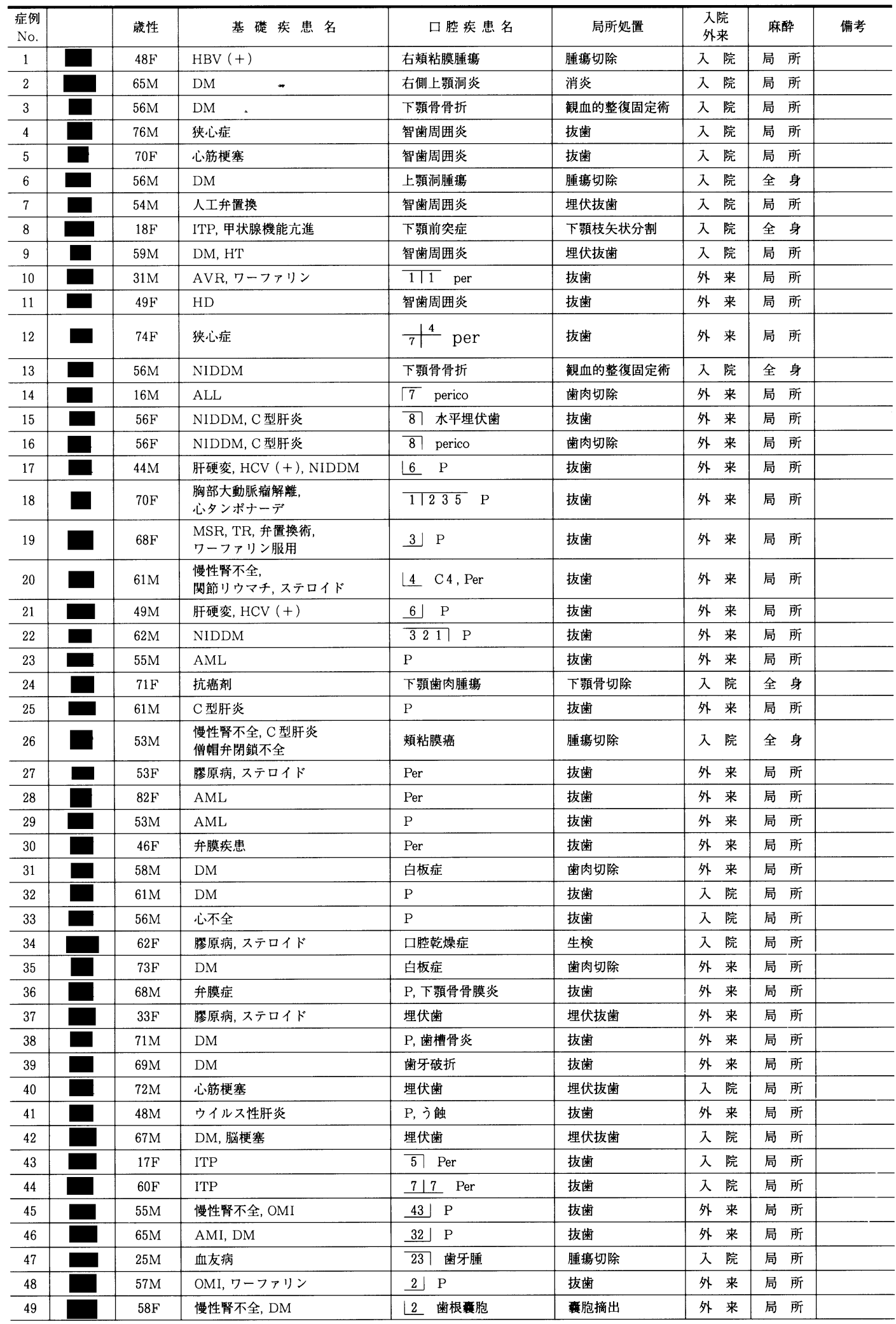


表 3 - 2 症例一覧

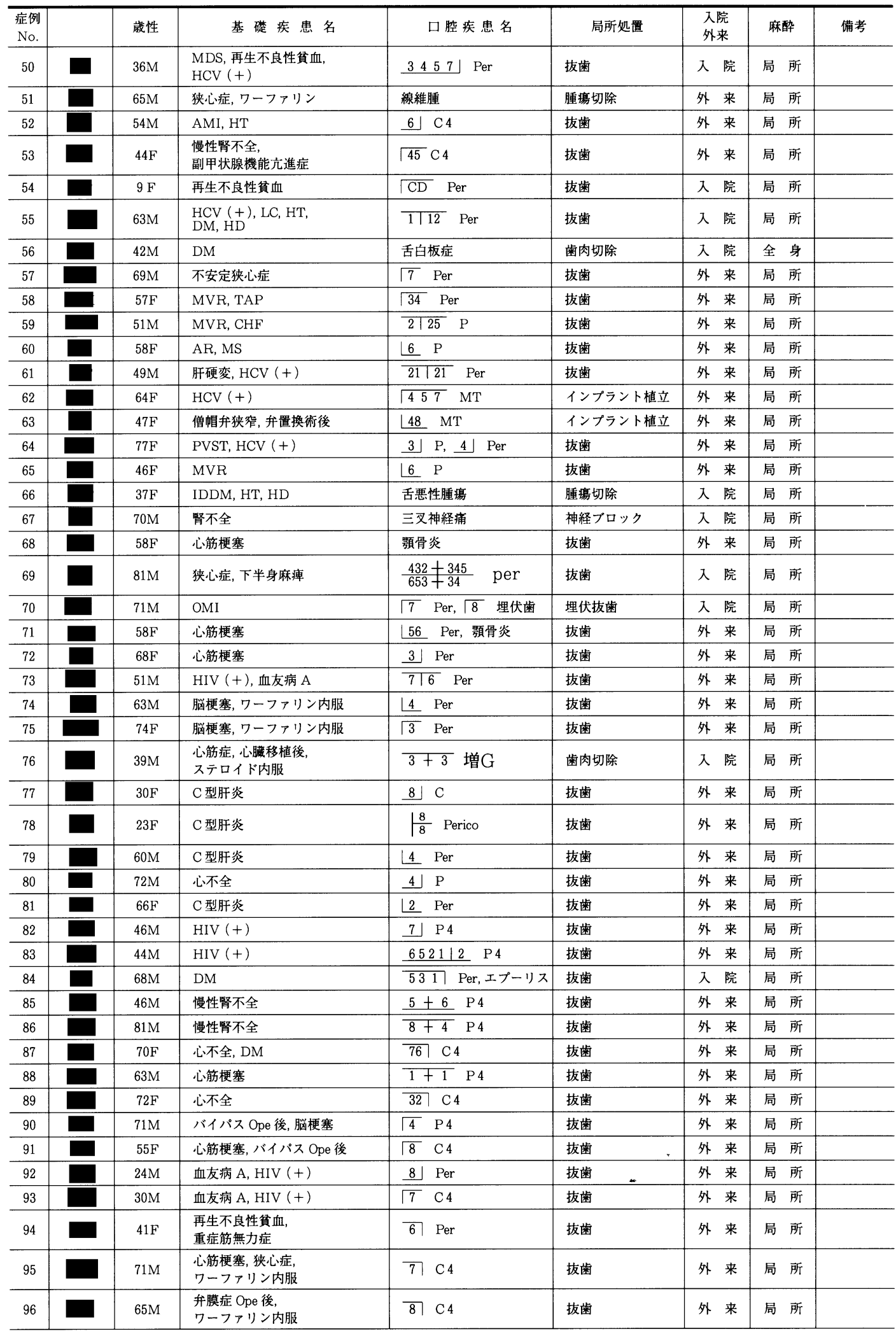


表 4 対象の性別·年代別症例数

\begin{tabular}{|c|c|c|c|c|c|c|c|c|}
\hline 性別 & $\sim 20$ & $21 \sim 30$ & $31 \sim 40$ & $41 \sim 50$ & $51 \sim 60$ & $61 \sim 70$ & $71 \sim$ & 計 \\
\hline 男 & $2^{-}$ & 3 & 3 & 8 & 16 & 17 & 9 & 58 \\
\hline 女 & 2 & 2 & 2 & 7 & 10 & 8 & 7 & 38 \\
\hline
\end{tabular}

(平均年齢 : 55.6歳)

表 5 基礎疾患 (単一症例) 別の症例数

\begin{tabular}{|c|c|c|c|c|c|c|}
\hline 基 & 礎 & 疾 患 & 名 & 症 & 例 & 数 \\
\hline 心 & & 疾 & 患 & \multicolumn{3}{|c|}{33} \\
\hline 糖 & & 尿 & 病 & \multicolumn{3}{|c|}{14} \\
\hline 血 & 液 & 疾 & 患 & \multicolumn{3}{|c|}{10} \\
\hline 透 & 析 & 患 & 者 & \multicolumn{3}{|c|}{10} \\
\hline 感 & & 染 & 症 & \multicolumn{3}{|c|}{13} \\
\hline \multicolumn{4}{|c|}{$\begin{array}{l}\text { 特殊薬物療 法 中 } \\
(\text { (ワーファリン, スティイド, 抗癌剤) }\end{array}$} & \multicolumn{3}{|c|}{$\begin{array}{c}21 \\
\text { (13例は心疾患と重複） }\end{array}$} \\
\hline \multicolumn{4}{|c|}{ 計 } & \multicolumn{3}{|c|}{87} \\
\hline
\end{tabular}

表 6 基礎疾患 (複数症例) の組合せと症例数

\begin{tabular}{|c|c|c|}
\hline 疾 患 名 & 症例数 & 備 \\
\hline 心 疾 患－糖尿病 & 2 & AMI, 心不全 \\
\hline 糖 尿 病一感染症 & 3 & $\mathrm{HCV}+$ 糖尿病 : 3 例 \\
\hline 血液疾患－感染症 & 4 & $\mathrm{HIV}+$ 血友病 : 3 例 \\
\hline & 9 & \\
\hline
\end{tabular}

の30\%であった. それらの術前, 術中, 術後の検查お よび処置は表 9 に示すように, どの口腔外科的処置に おいても外来で行った症例群に比べて平均の検査およ び処置数が多かった. その理由としては，基礎疾患の 重い患者で全身管理のために入院を必要とするような 症例や口腔外科的処置の際の侵襲が大きい症例が入院 症例であったことが考えられるが，それ以外に入院時 の手続き, オリエンテーションや入院のためのルーチ ン検査なども項目の中に加えられており，それらも入
表 7 口腔外科的処置および症例数

\begin{tabular}{|c|c|c|c|}
\hline \multirow{2}{*}{ 口腔外科的処 置 } & \multicolumn{3}{|c|}{ 症 例 数 } \\
\hline & 外来 & 入院 & 計 \\
\hline 普 通 抜 歯 & 57 & 11 & 68 \\
\hline 埋 伏 歯 抜 歯 & 1 & 5 & 6 \\
\hline 囊 胞 摘 出 & 1 & 0 & 1 \\
\hline 歯 肉 切 & 4 & 2 & 6 \\
\hline 腫瘍 切 除 & 1 & 5 & 6 \\
\hline 顎骨骨折の観血的整復 & 0 & 2 & 2 \\
\hline インプラント植立 & 2 & 0 & 2 \\
\hline そ＜wide>の＜wide>他 & 0 & 5 & 5 \\
\hline （消炎, 神経ブロック, 生検など） & & & \\
\hline 計 & 60 & 30 & 96 \\
\hline
\end{tabular}

表 8 有病者に対する口腔外科処置時の術前, 術中, 術後の平均検查㧍よび処置数

(対象96症例)

\begin{tabular}{c|c|c|c}
\hline \multirow{2}{*}{ 総検査 · 処置数 } & \multicolumn{3}{|c}{ 平均検査 処置数 } \\
\cline { 2 - 4 } & 外来 & 入院 & 計 \\
\hline 術前 13 & 3.5 & 7.9 & 4.9 \\
術中 14 & 3.4 & 5.7 & 4.1 \\
術後 15 & 3.1 & 6.0 & 4.0 \\
\hline & 10.0 & 19.6 & 13.0 \\
\hline
\end{tabular}

院症例群で平均の検査および処置数が多い理由である と考える.

3 ) 抜歯症例における検査および処置数の健常者群 との比較

抜歯症例について有病者群と健常者群との間で術前, 術中, 術後の検查および処置数にどのくらいの差があ るかを検討した. 今回の対象症例中, 抜歯を行ったの は74例である. その74例の抜歯において術前, 術中, 術 後の検査および処置の合計は外来では平均 10.2 項目, 
表 9 有病者に対する口腔外科的処置別の術前, 術 中, 術後の平均検査および処置数

\begin{tabular}{|c|c|c|c|c|}
\hline \multirow[b]{2}{*}{ 口腔外科的処置 } & \multicolumn{2}{|c|}{ 外 来 } & \multicolumn{2}{|c|}{ 入 院 } \\
\hline & 症例数 & $\begin{array}{l}\text { 術前·中·後 } \\
\text { 平均 検 査 } \\
\text { 処 置 数 }\end{array}$ & 症例数 & $\begin{array}{l}\text { 術前. 中. 後 } \\
\text { 平均 検 査 } \\
\text { 処 置 数 }\end{array}$ \\
\hline 普通抜歯 & 57 & 10.2 & 11 & 15.9 \\
\hline 埋伏歯抜歯 & 1 & 11.0 & 5 & 19.8 \\
\hline 襄胞摘出 & 1 & 16.0 & - & - \\
\hline 歯肉切除 & 4 & 6.5 & 2 & 21.5 \\
\hline 腫瘍切除 & 1 & 16.0 & 5 & 23.6 \\
\hline 顎骨骨折の観血的整復 & - & - & 2 & 24.5 \\
\hline インプラント植立 & 2 & 5.0 & - & - \\
\hline $\begin{array}{l}\text { その他 } \\
\left(\begin{array}{l}\text { 消炎,神経ブロック, } \\
\text { 生検 }\end{array}\right)\end{array}$ & 0 & 0 & 5 & 21.0 \\
\hline
\end{tabular}

表10 抜歯症例における術前, 術中, 術後の 平均検査および処置数

\begin{tabular}{c|cc|c|c|c|c}
\hline \multirow{2}{*}{ 対象 } & \multirow{2}{*}{ 症例数 } & \multicolumn{4}{|c}{ 平均検査 ·処置数 } \\
\cline { 3 - 7 } & & & 術前 & 術中 & 術後 & 計 \\
\hline \multirow{3}{*}{ 有病者 } & 外来 & 58 & 3.6 & 3.5 & 3.1 & 10.2 \\
& 入院 & 16 & 7.4 & 5.1 & 4.7 & 17.2 \\
\cline { 4 - 7 } & 計 & 74 & 5.5 & 4.3 & 3.9 & 13.7 \\
\hline 健常者 & & 30 & 2.6 & 1.0 & 1.6 & 5.2 \\
\hline
\end{tabular}

入院の場合は平均 17.2 項目であった。これに対して健 常者群ではわずか平均 5.2 項目と対象群の約 3 分の 1 であった (表10).いいかえると, 有病者の抜歯は健常 者の場合よりも約 3 倍の検査および処置が必要であっ たことになる。

4 ) 基礎疾患別にみた平均検査および処置数

次に術前, 術中, 術後の検査および処置数を基礎疾 患別にみると, 基礎疾患が単一の症例では透析患者が 平均 16.7 項目, 糖尿病が平均 16.1 項目と最も多く, 次い で心疾患の13項目であった. 全疾患についてみると平 均12.8項目であった（表11）.

一方, 疾患を複数にもっている症例 9 例について同 様の検討をした結果, 心疾患と糖尿病を合併していた 2 例が平均 20 項目と著しく項目が多かった以外は 9 例 の平均も11.2処置と単一疾患の症例との差はなかった (表12).
表11 基礎疾患 (単一症例) 別口腔外科的処置時の 術前, 術中, 術後の平均検査および処置数

\begin{tabular}{c|c|c}
\hline 基礎疾患名 & 症例数 & 平均検査 ·処置数 \\
\hline 心 疾 患 & 33 & 13.0 \\
糖 尿 病 & 14 & 16.1 \\
血液疾患 & 10 & 11.4 \\
透析患者 & 10 & 16.7 \\
感 染 症 & 13 & 8.3 \\
\hline 薬物療法 & $21 *$ & 11.7 \\
\hline 計 & $102 *$ & 12.6 \\
\hline \multicolumn{2}{|c}{ (*うち13例は心疾患と重複 }
\end{tabular}

表12 基礎疾患（複数症例）別口腔外科的処置時の 術前, 術中, 術後の平均検査および処置数

\begin{tabular}{c|c|c}
\hline 疾 患 名 & 症例数 & 平均検査 ·処置数 \\
\hline 心 疾 患一糖尿病 & 2 & 20.0 \\
糖 尿 病一感染症 & 3 & 5.7 \\
血液疾患一感染症 & 4 & 11.0 \\
\hline & 9 & 11.2 \\
\hline
\end{tabular}

\section{5 . 術前, 術中, 術後の検査および処置の平均所}

\section{要時間について}

検査および処置に際してどのくらいの時間を必要と するかを調査し, 検討を行った. 結果は次のとおりで ある、

1 ) 術前検査および処置

術前検查および処置として設定した13項目に対して 各症例毎に行った項目をチェックし，96例中何症例が その検査および処置を行ったか集計し，また，その時 に要した時間から平均時間を算出した。術前検査およ び処置としては, 他科へのコンサルテーションが84例 に, 次いでバイタルチェック70例，血圧測定63例，以下 血液検査, 術前投薬の順で施行されたものが多かった. 各項目の平均所要時間は, 最短は血圧測定の8.3分, 最 長はスプリント作製の57.1分で，13項目全体でみると 1 項目あたり平均所要時間は22.8分であった（表13）. 有病者に対する術前検査および処置の平均項目数は前 
表13 術前検査および処置別平均所要時間

\begin{tabular}{l|c|c}
\hline \multicolumn{1}{c|}{ 術前の検査および処置 } & 症例数 & $\begin{array}{c}\text { 平均所要 } \\
\text { 時間 }(\text { 分 })\end{array}$ \\
\hline 1. 他科へのコンサルテーション & -84 & 30.9 \\
2. バイタルチェック & 70 & 9.1 \\
3. 血圧測定 & 63 & 8.3 \\
4. 血液検查 & 56 & 12.0 \\
5. 術前投薬 & 50 & 14.3 \\
6. 心電図測定 & 32 & 16.0 \\
7. 入院手続き, オリエンテーション & 29 & 17.5 \\
8. 術前薬物コントロール & 26 & 16.0 \\
9. 栄養管理, 指導 & 19 & 21.2 \\
10. スプリント作製 & 15 & 57.1 \\
11. その他特殊検査 & 11 & 24.4 \\
12. その他の術前処置 & 10 & 26.7 \\
13. 輸血準備処置 & 7 & 39.0 \\
\hline
\end{tabular}

1 検査あるいは処置当たりの平均所要時間 22.8 分

表14 術中検査および処置別平均所要時間

\begin{tabular}{l|c|c}
\hline \multicolumn{1}{c|}{ 術中の検査および処置 } & 症例数 & $\begin{array}{c}\text { 平均所要 } \\
\text { 時間 }(\text { 分 })\end{array}$ \\
\hline 1. 麻酔法 & 90 & 27.1 \\
2. バイタルチェック & 59 & 23.7 \\
3. 局所止血 & 62 & 18.5 \\
4. 血圧測定 & 52 & 48.0 \\
5. 心電図モニタリング & 33 & 79.8 \\
6. 点滴静注 & 29 & 128.0 \\
7. その他のモニター & 17 & 81.1 \\
8. スプリント使用 & 15 & 18.0 \\
9. 術中酸素吸入 & 7 & 97.3 \\
10. 他科へコンサルテーション & 7 & 67.5 \\
11. 鎮静法 & 6 & 44.0 \\
12. 輸血 & 6 & 118.0 \\
13. 術中薬物内服 & 2 & 5.0 \\
14. その他の術中処置 & 1 & 15.0 \\
\hline
\end{tabular}

1 検査あるいは処置当たりの平均所要時間 43.8 分 （輸血，点滴時間を除く）

述（表 8 ）のように4.8項目であり，したがって 1 例に おける術前の検査および処置に要する平均所要時間は 109.4分となった. これを最も頻度の高かった 5 項目の みに限定しても75.1分かかるという結果であった。
表15 術後検査および処置別平均所要時間

\begin{tabular}{l|c|c}
\hline \multicolumn{1}{c|}{ 術後の検査および処置 } & 症例数 & $\begin{array}{c}\text { 平均所要 } \\
\text { 時間 }(\text { 分 })\end{array}$ \\
\hline 1. 薬物投与 & 74 & 10.0 \\
2. バイタルチェック & 54 & 21.8 \\
3. 血圧測定 & 54 & 11.5 \\
4. 他科へのコンサルテーション & 31 & 22.0 \\
5. 点滴静注 & 29 & 42.5 \\
6. 血液検査 & 23 & 13.1 \\
7. 特別なロ腔清掃指導 & 20 & 18.5 \\
8. 感染器具類の処理・消毒 & 19 & 31.3 \\
9. 術後薬物コントロール & 18 & 16.9 \\
10. 心電図測定, モニタリング & 18 & 13.5 \\
11. 栄養管理, 指導 & 17 & 26.4 \\
12. スプリント調整あるいは除去 & 12 & 17.5 \\
13. その他の術後処置 & 8 & 16.7 \\
14. その他の特殊検査 & 3 & 12.5 \\
15. 輸血 & 3 & 130.0 \\
\hline
\end{tabular}

1 検査あるいは処置当たりの平均所要時間 18.9 分

（輸血時間を除く）

\section{2 ) 術中検查および処置}

術中の検査および処置は14項目を設定したがそのう ちでは麻酔法, バイタルチェック, 局所止血, 血圧測 定, 心電図モニタリングなどの順に施行されたものが 多かった（表14）。術中の検査あるいは処置 1 項目あた りの平均所要時間は43.8分であった. 術中は平均 4 項 目行っていることから，1例の所要時間は平均 175.2 分 であるといえる.最も頻度の高かった 4 項目に限定し ても116.3分となり，かなりの時間を要することが明ら かである。

3 ) 術後検査および処置

術後検査および処置は15項目を設定した. 最も多かっ たのは内服薬の投与で, 96例中74例が施行していた. 次いでバイタルチェック, 血圧測定, 他科へのコンサ ルテーション, 点滴静注, 血液検査などの順である (表15).

術後の検査あるいは処置 1 項目あたりの平均所要時 間は18.9分で 1 例あたり平均 4.0 項目（表 8 ）であった ことから，1例の術後検査および処置に要する時間は 平均75.6分となった。

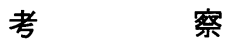

有病者に口腔外科的処置を行う際にはその侵襲が全 身に影響を及ほし，ときには重篤な全身状態を惹起す ることはよく知られている $\left.{ }^{3}, 4\right)$. そのため, 有病者の 
口腔外科的処置は日常の臨床においては回避されるこ とが多い2．しかし，口腔内に病変や感染巣が存在す ることは患者に苦痛を与えるばかりでなく, 全身状態 を悪化させたり, 全身疾患の治療経過に悪影響を及ほ し，ときには敗血症などを引き起こし，生命の危険を 招くことも決してまれではない5).したがってリスク が高いからといって, 口腔疾患をそのまま放置するわ けにはいかない患者も少なくない.

今回われわれはそのような患者にあえて口腔外科的 処置を行わなければならないとしたら術前, 術後を通 していかなる検査や処置が必要であるのか, またその ためにどのくらいの時間がかかるのかなどを明らかに する目的で調査し, 健常者との比較も行った。その結 果, 前述のように種々の術前, 術中, 術後の検査およ び処置が行われ，また多くの時間を費やしていること が明らかとなった.すなわち, 今回の調査対象となっ た患者の術前, 術中, 術後の検査および処置は, 外来 症例においては9.9項目, 入院して局所処置を行った症 例においては19.6項目が行われ, 入院症例では外来症 例の 2 倍であることが明らかになった. 術前, 術中, 術後の検査および処置のうちでは術前が最も多い結果 となり，このことは有病者の歯科口腔外科処置を行う に際しては, 術前に十分な診査と対策を立てることの 重要性を示しているものといえる.

外来, 入院を合わせると術前の検査および処置は 13 項目中 4.9 項目, 術中は4.1と術後は4.0で, 合計すると 1 例当たり平均 12.8 項目の検査および処置を必要として いた.

口腔外科的処置別に検討した結果は, 腫瘍切除およ び囊胞摘出の症例がどちらも16項目と多かったが, 抜 歯においては普通抜歯と埋伏歯抜歯とでの差はなかっ た。

抜歯を行った症例を健常者群と比較した結果, 対象 群では健常者群の 3 倍の検査および処置が必要である ことが明らかになった。

基礎疾患別にみると単一疾患の症例では透析患者 16.7 項目と糖尿病 16.1 項目が最も多く，また複数の基 礎疾患を有する症例のうちでは心疾患と糖尿病の合併 症例が, 平均 20 項目と最も検査および処置数が多かっ た.このことは, このような疾患では全身の藏器に障 害をきたすという特徴から, 十分な検査および処置の もとでなければ口腔外科的処置を行えないということ を示しているものといえよう。

さらに検査および処置に要する時間を検討した結果, 術前は 1 項目あたり平均22.8分で，1例に要する時間 は109.4分であった. 術中は 1 項目あたり平均43.8分で 合計175.2分, 術後は 1 検査あるいは処置当たり平均 18.9分で，1例で合計75.6分を要していた.

以上のことから有病者の口腔外科的処置に際しては 1 例当たり平均 13 項目の術前, 術中, 術後の検査およ
び処置を行い, その所要時間の合計は360.2分すなわち 6 時間であることが明らかとなった。

今回の対象症例は全身的にはきわめてリスクの高い 患者であったが不測の合併症をきたした症例は 1 例も なかった，そのことは各施設とも術前に十分な検討を 行い, さらに術中や術後にも数々の検査や処置を十分 に時間をかけて行ったことにより，安全に口腔外科的 処置が行えたことを示したものといえよう。いいかえ ればそれだけ十分な時間をかけ，また各種の術前，術 中, 術後の検査および処置を行わなければ, リスクの 高い患者に対しては安全に口腔外科的処置を行えない ことを今回の調査は具体的に示したともいえよう.

なお，重篤な疾患を有する患者においては目的とす る処置を行えないこともまれではない。今回の調査で は処置を行ったもののみを対象とし, 行えなかった症 例が各施設にどのくらい存在したか, どのような疾患 で行えなかったかなどについての調査は行っていない ので不明である。それらの症例について分析すること も興味ある問題であり, 今後必要であると考える。

結

語

10施設において心疾患, 糖尿病, 血液疾患, 透析患 者, ウイルス感染, 特殊な薬物治療患者の計96例を対 象に, 口腔外科的処置を行う際に必要な術前, 術中, 術後の検査および処置の内容やその所要時間などを検 討した。

その結果は 1 例当たり平均13項目の術前, 術中, 術 後の検査および処置と, 360.2 分の時間を必要とした。 また, 入院症例は外来の約 2 倍, 健常者の抜歯症例と の比較においては有病者群は約 3 倍の検査および処置 が, 本来の口腔外科的処置に加えて必要であることが 明らかになった。

\section{文献}

1）厚生省統計協会 : 国民衛生の動向・構生の指標. 43: 132-137, 1996.

2) Hupp, J.R.: Contemporary oral and maxillofacial surgery. Peterson, L.J., Ellis, E., et al eds. The C.V. Mosby Company, St Louis, 1988. p27-45.

3）扇内秀樹, 日高敏郎, 他 : 人工透析患者で手術 後死亡した 2 症例. 有病者菌科医療 $4: 35-41$, 1995.

4）吉田博昭, 別所和久, 他：口腔外科手術患者に おける全身的術中偶発症について.日口外誌 41: 533-536, 1995.

5) 中䲶 哲, 植田章夫, 他: 糖尿病患者に発生し た重症歯性感染症の 1 例. 有病者歯科医療 5 : 132-137, 1997. 